\section{Some Enzymatic Properties of Suspensions of Parenchymatous Liver Cells}

The heterogeneous population of rat liver ${ }^{1}$ has led to a discussion of the interpretation of enzyme activities based on whole liver or whole liver proteins? Recent interest in the properties of suspensions of parenchymatous liver cells ${ }^{3,4}$ has raised the possibility of using such cells as reference base for enzyme determinations. By shaking rat liver slices in calciumfree citrated Krebs-Ringer phosphate buffer with added glucose, passing the slices through graded sieves to break them into the component cells, centrifuging and resuspending the sediment, we have shown ${ }^{5,6}$ that the cells of such suspensions leak most of their content of glutamic pyruvic transaminase while retaining glutamic oxalacetic transaminase. Subsequent studies have shown that in general between 70 and 90 per cent of lactic acid dehydrogenase, 'TPN-linked' isocitric dehydrogenase and glucose-6-phosphate dehydrogenase are similarly lost from the cells in the course of making the preparation. The leakage of lactic acid dehydrogenase was not prevented by making the medium between $0.01 \mathrm{M}$ and $1 M$ in pyruvate both with and without the addition of $2-5$ per cent bovine albumen fraction $V$, by the presence of adenosine triphosphate $(750 \mathrm{mgm}$. per cent) crystalline human oxyhæmoglobin (5-10 per cent) and carbonic anhydrase, the latter two being used both singly and in combination. By making the medium 20 per cent in washed human red blood cells the leakage appeared to be inhibited?

Studies with Evans blue have shown, however, that this could be accounted for by the amount of supernatant trapped in the loosely packed sediment. The leakage of enzyme could not be inhibited either by increasing the concentration of glucose to $500 \mathrm{mgm}$. per cent and using a medium containing amino-acids, with the addition of insulin, $\alpha$-keloglutarate, adenosine and $\alpha$-tocopherol which have been found to maintain oxydative phosphorylation in perfused rat liver ${ }^{8}$, or by substituting ethylene diamine tetra-acetate for citrate in equimolar amounts. Likewise, the addition to the medium of whole liver homogenate prepared from a remainder of the rat liver used in the preparation of the cells did not result in retention of enzyme by the cells if the cells were washed once by resuspending in fresh medium and centrifugation. This was found to be the case whether pyruvate was added to the medium or not. Studies of the leakage from rat liver slices shaken for a period of $1 \mathrm{hr}$. at $37^{\circ} \mathrm{C}$. showed that on an average only 50 per cent of the enzyme (expressed on a protein basis) remained in the slices at the end of that time. This was found at $p \mathrm{H} 5 \cdot 0$, $6 \cdot 0,7 \cdot 0$ and $7 \cdot 3$, and for a molarity varying from $0 \cdot 3 \mathrm{M}$ to $1 \cdot 8 \mathrm{M}$.

Two of the particulate enzymes, glutamic dehydrogenase and glucose-6-phosphatase, remained in the cells in the proportion expected if no leakage had occurred (Table 1).

It, therefore, appears that of the predominately 'soluble' enzymes so far tested only glutamic oxalacetic transaminase remained within the cell. The overall recovery of protein from the cells and from the supernatants was more than 90 per cent and the amount of protein per cell was generally between 80 and 90 per cent. The majority of the protein component of the cell is, therefore, retained. The amount of cellular protein which has enzymatic activity is not known with certainty but has been estimated as being about 60 per cent by Lang' Between one-half and one-third of the cellular protein is in the 'soluble fraction' of the cell ${ }^{10}$. If it is further assumed that almost all the non-enzymic cellular protein is in the particulate fraction, the average of 10-20 per cent of protein lost from the cell could be accounted for largely by enzymic protein from the 'soluble' fraction.

The activities of glutamic oxalacetic transaminase, glutamic dehydrogenase and glucose-6-phosphatase in rat liver can, however, be expressed on a cellular basis and are given in Table 2 .

Further work on enzyme leakage from morphologically intact liver cells is in progress.

Our thanks are due to Dr. H. S. Wiggins for constant help and advice and to the Michigan State Board of Alcoholism and the Horace H. Rackham School of Graduate Studies for grants in support of this work.

Keith S. Henley

Ole Sorensen

H. Marvin Pollard

Department of Internal Medicine,

University Medical Center, Ann Arbor, Michigan. ${ }^{1}$ Daoust, R., in 'Liver Function', Ed. by R. W. Brauer (Amer. Inst.
Biol. Sci., 1958).

${ }^{2}$ Schmidt, E., Schmidt, F. W., and Wildhirt, E., Kli. Wochnschr., 36, $227(1958)$.

${ }^{3}$ Laws, J. O., and Strickland, L. H., Nature, 178, 309 (1956).

" Rutter, W.'J., Fed. Proc., 18, 314 (1959).

5 Henley, K. S., Wiggins, H. S., Pollard, H. M., and Dullaert, E., Ann. N.Y. Acad. Sei., 75, 270 (1958)

${ }^{6}$ Henley, K. S., Wiggins, H. S., Pollard, H. M., and Dullaert, E. Gastroenterol., 36, 1 (1959).

7 Henley, K. S., and Soresnsen, O., Fed. Proc., 18, 245 (1959)

Dawkins, M. J. R., Judah, J. D., and Rees, K. R., J. Path. and Bact., 77,257 (1050).

'Lang, K.' in 'Biologie und Wirkung der Fermente' (Springer

10 Henley, K. S., and Dułlaert, E. (unpublished).

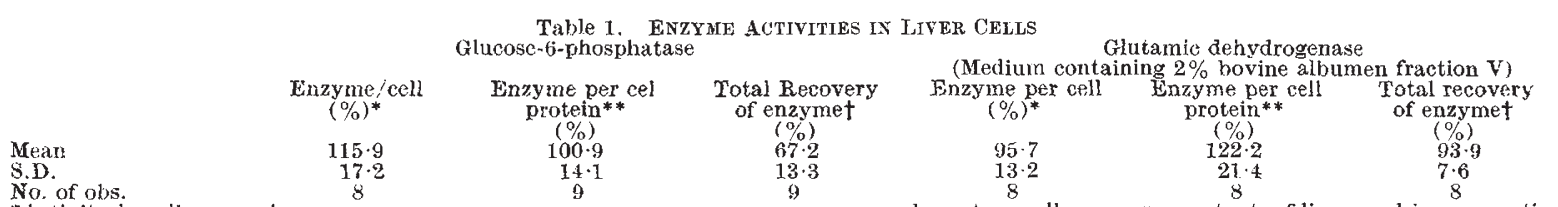

No. of ols.

*Aetivity in cell suspension $17 \cdot 2$

Activity in control $x$ cell yield

parenchymatous cells per mgm. wet $w \mathrm{t}$. of liver used in preparation

**Specific activity of cell suspension

Specific activity of control homogenate

†Activity of cell suspension/activity of media

Activity of control
Note: Low total recovery of glucose-6-phosphatase was found to be due to loss of enzyme in the medium.

Table 2. ENZYME ACTIVITIES ON A CEILULAR BASTS

Enzyme

Glutamic oxalacetic transaminase

Glucose-6-phosphatase

Glutamic dehydrogenase

$\left(\mu \mathrm{mol} . / 10^{7}\right.$ cells $/ \mathrm{hr}$.) at $37 \mathrm{C}$.
ENZYM

$\begin{array}{cc}\text { Activity } & \text { S.D. } \\ 719 & 230 \\ 0.063 & 0.013 \\ 96 \cdot 3 & 23\end{array}$

